\title{
Offprinted from
}

\author{
MODERN LANGUAGE REVIEW \\ VOLUME 110, PART 4 \\ OCTOBER 2015
}

(c) Modern Humanities Research Association 2015 
That link between the aesthetic and the political is shown to be crucial for an understanding of Parker's life and work. He was born into a working-class Protestant family in east Belfast in 1941, and was educated at Queen's University in Belfast, studying there at much the same time as Seamus Heaney, Seamus Deane, and many others who would develop careers as writers. That environment inspired the young Parker: 'Queen's is not an oasis, but it is a power-store,' he wrote in 1962. 'If enough people light matches, we can blast our way out of this cultural siege and then start the war in earnest' (p. 22).

Parker's remarks were metaphorical, of course, yet he may have been showing a subliminal awareness that Northern Ireland was a powder-keg in another, more significant respect: the sectarianism that had dominated life there for decades would soon result in a Civil Rights movement, which later gave way to violent conflict between Catholics and Protestants. The ensuing 'Troubles' continued for the rest of Parker's life. As a portrait of a writer grappling with the responsibilities of living in a society at war, Richtarik's book has consequences that go far beyond literature about Northern Ireland.

Richtarik also presents a fascinating and at times moving portrait of Parker himself. She is honest about Parker's flaws and his private failings-but she also captures compellingly his bravery. Parker lost his leg due to cancer at the age of twenty, yet that trauma seems, if anything, to have made him more determined to succeed. And that determination persisted for the rest of his life. It was evident in his desire to push Irish drama into new areas, and in his willingness to disrupt our understanding of the differences between popular and literary culture. And it was evident too in his many attempts to imagine the possibility that Northern Ireland could eventually find peace. Stewart Parker was, fundamentally, an original artist—and Richtarik shows convincingly that he deserves to be known better.

National University of Ireland, Galway

Patrick Lonergan

9/11 and the Literature of Terror. By Martin RANDALl. Edinburgh: Edinburgh University Press. 2011 (pbk 2014). 184 pp. $£ 65$ (pbk £19.99). ISBN 978-07486-3852-9 (pbk 978-0-7486-9119-7).

Studies of 9/11 literature are thriving. At least two have been published since Martin Randall's book first came out in 2011-Eva Kowal's The 'Image-Event' in the Early Post-9/11 Novel: Literary Representations of Terror after September 11, 2001 (Kraków: Jagiellonian University Press, 2012) and Richard Gray's After the Fall: American Literature since 9/11 (Chichester: Wiley-Blackwell, 2011) - yet Randall's 9/11 and the Literature of Terror (now in paperback) remains timely and worthwhile. Among its strengths are its range-discussing essays, plays, poems, novels, films, and short stories-and its focus on the evolution in responses to the attacks, from respectful and politically conservative to increasingly complex and critical. Like other scholars, Randall prefers formally experimental attempts to engage with 9/11, and argues that 'realist fiction generally failed to identify and describe the 
“wounds" left after the attacks' (p. 3). In part, Randall suggests, this is due to the uniquely visual nature of the attacks, which has left language struggling to describe them adequately, but the visual image itself has been left surrounded by a 'profound uncertainty', as attested by the many conspiracy theories-themselves narrative in form-surrounding the attacks that abound on the Internet. In the light of these challenges, Randall finds that more 'mixed' forms have succeeded better in shedding light on $9 / 11$ (p. 15).

Randall begins with a chapter on some early responses, including an article published by Ian McEwan on 12 September 2011, and an essay by Don DeLillo that appeared two months later, both 'impassioned' and 'politically intemperate', while 110 Stories: New York Writes after September 11, published a year later, gives way to a more 'mournful' work. These are valuable testimonials, Randall suggests, but limited by their proximity to the attacks. A similar problem arises with Martin Amis's The Second Plane (2008), the subject of Randall's second chapter. This time the problem is not proximity but personality-Amis's hijackers curiously resemble characters from his other works-and personal politics, as Amis ends the volume with a 'morally outraged, emotionally charged attack on radical Islamism' (p. 61). Randall concludes that Amis ultimately fails to 'engage with the "otherness" of the hijackers', and falls back on standard satirical tropes (excrement, sex, bodily decay) to ridicule them.

In the next chapter, on Frédéric Beigbeder's formally innovative Windows on the World, Randall finally examines a text that appears to 'shed more light upon the meanings of the attacks' than the others. Beigbeder is not only not a New Yorker, but he is French, a literary bad boy of sorts, and he flaunts it. Randall suggests that, by taking great 'aesthetic and ethical risks', Beigbeder manages to create a work that succeeds where others have failed because it remains 'open to self-questioning, irony, self-reflection [...] and an awareness of its own limitations' (p. 76). Another work that Randall admires is Simon Armitage's Out of the Blue, a film and poem that first appeared on television in 2006. The next work that Randall examines and approves is also a film, James March's 2005 documentary about Frenchman Philippe Petit's 1974 cable walk between the two towers, which happens to be 'about' the towers in 'intriguing and subtle ways' even though it is not overtly about $9 / 11$ at all (p. 88).

Randall turns to two plays in the next chapter, Neil LaBute's The Mercy Seat and Anne Neilson's The Guys, which allow him to engage with the complex issue of gender politics in the context of the attack's aftermath. A final chapter, on Don DeLillo's Falling Man (2007), is oddly descriptive and seems undeveloped, probably because Randall is too polite to come out and say what the rest of his book implies: namely, that DeLillo's realist novel fails to deliver a satisfying account of 9/11. Randall's conclusion examines a review essay on Falling Man in the Guardian from 2007 and a short story by Mohsin Hamid, author of The Reluctant Fundamentalist (2006). By discussing these two works, published in a newspaper and a literary magazine respectively, Randall tacitly underscores his dissatisfaction with 9/11 literature, especially novels, and sketches out a direction that he believes, 
or hopes, writing and art on 9/11 will take in future years: towards a greater acknowledgement of politics and ideology as 'social and emotional' realities in the world.

UNIVERSITY OF LAUSANNE

AgniesZKa Soltysik Monnet

Rewriting Saints and Ancestors: Memory and Forgetting in France, 500-1200. By Constance Brittain Bouchard. Philadelphia: University of Pennsylvania Press. 2015. xiv +362 pp. $£ 52$. ISBN 978-0-8122-4636-0.

Drawing on her fine earlier work on cartularies, monasticism, noble families, and the construction of the past, Constance Brittain Bouchard seeks here to bring the selectivity and malleability of historical memory to the forefront of early medieval French history. Over the last quarter of a century, historians such as Patrick Geary, Walter Goffart, Amy Remensnyder, and Bouchard herself have highlighted how medieval authors habitually projected contemporary needs and ambitions onto their presentations of the past. Rewriting Saints and Ancestors does not radically challenge these approaches, but it does serve to synthesize the fast-growing body of literature on medieval memory studies and to highlight the value of such approaches to the Merovingian period, as previous work has tended to crystallize around the Carolingian and post-Carolingian centuries.

Bouchard adopts a reverse-chronological approach 'in order to emphasize that [her] central concern is not particular events but rather the memory of those events' (p. 6). Though the title promises a general study of France, the overwhelming geographic focus is Burgundy and southern Champagne. Chapters 1-4 explore documentary practice and memory in the long twelfth century. Bouchard shows how cartularies (collections of earlier charters) were composed by monks trying to make sense of an increasingly obscure past, and were demonstrably produced for internal record-keeping and commemoration rather than external legal validation. Likewise, chroniclers at Sens and Flavigny creatively manipulated the past to suit present needs. Chapter 4 deserves to be read by any historian using polyptyques as a source for ninth-century history. Because the social and economic landscape of Europe had changed so dramatically between 900 and 1200 , these ninth-century inventories made little sense to twelfth-century scribes whose copies historians are often reliant upon. Many polyptyques were thus left to oblivion, while the ones that were copied out (and have thus survived) are highly problematic.

Following a chapter outlining the ingenuity and profusion of ninth-century forgers, Chapters 6-10 closely examine the eighth century, detailing how the Carolingians justified their seizure of the Frankish throne and constructed a mythical dynastic past, and how the Merovingians and Carolingians respectively treated monasteries (as well as how monks remembered that treatment). Some of this (e.g. the Carolingians' systematic denigration of the Merovingians) is well-trodden ground, but Bouchard offers fresh insights in other areas (e.g. new conceptions of noble lineage following the Carolingian takeover). A chief contention in this 